\title{
Galactofuranosylated Galactocerebrosides, a New Drug Delivery System for Ceramides to Colon
}

\author{
Dumitru Petru Iga* and Silvia Iga
}

Faculty for Biology, Splaiul Independentei 95, Bucuresti-5, R-76201, Romania

\begin{abstract}
Two isomeric partially acetylated galactocerebrosides, $\beta$ - $D$-galactopyranosyl (2,3,4-tri-O-acetyl)- and $\beta-D$ galactopyranosyl (2,4,6-tri-O-acetyl)-1'(3'-O-acetyl)ceramide, were prepared from galactocerebroside and sulfatide, respectively. Their galactofuranosylation produced $\beta$ - $D$-galactofuranosyl-6- and $B$ - $D$-galactofuranosyl-3- $\beta-D$ galactopyranosyl-1'ceramide, as demonstrated by ${ }^{1} \mathrm{H}$ and ${ }^{13} \mathrm{C}$ NMR spectra as well as by chemical means.
\end{abstract}

Keywords: $\quad$ B-D-galactofuranosyl-6-ß-D-galactopyranosyl-1'ceramide, $\quad$-D-galactofuranosyl-3- $\beta$-D-galactopyranosyl1 'ceramide, Koenigs-Knorr synthesis, ${ }^{1} \mathrm{H}$ and ${ }^{13} \mathrm{C}$ NMR spectroscopy.

\section{INTRODUCTION}

Colon drug delivery systems have to overcome several barriers presented by gastrointestinal tract [1]. A large variety of compounds and approaches have been used or suggested as drug delivery systems destined to release biologically active compounds to the colon $[2,3]$. Amino acids have been used as prodrug precursors both as monomers [4] and oligomers [5]. Exceptionally adequated for colon delivery of salycilic acid proved salycyl-L-glutamic acid [6]. On the basis of in vitro experiments, it was proved that poly-(Laspartic acid) ester of dexamethazone presented maximum hydrolytic activity in caecum and colonic contents of rats [7]. The following glycosides of dexamethasone, prednisolone, hydrocortisone and fluorocortisone have been synthesized as prodrug candidates, all in beta configuration: $D$ glucosides, $D$-galactosides and $D$-cellobioside [8]. $\beta$ Glucuronidase production by bacteria of the lower gastrointestinal tract was exploited by preparation of $\beta$-glucuronides of dexamethazone and budenoside [9]. Ceramide $\beta$ glucuronide was prepared in order to prevent the cleavage in the small intestine, of orally administered glycosphingolipids, and thus enhancing the amount of ceramides and sphingosine reaching the colon [10].

In a pioneering work, $\beta-D$-galactofuranosyl-6- and $\beta-D$ galactofuranosyl-3- $\beta-D$-galactopyranosyl-1'ceramide have been synthesized from galactocerebroside and sulfatide, respectively, in a tentative to prove that they could constitute an efficient drug delivery system for ceramides to colon.

\section{MATERIALS AND METHODOLOGY}

\section{Materials}

Florisil and DEAE-Sephadex A-25 were from Sigma. $D$ Galactose, acetic anhydride, benzoyl chloride, pyridine, $\mathrm{HBr}$ (32-33\% in glacial acetic acid), ready-to-use glass plates covered with silica gel 60 for thin layer chromatography

*Address correspondence to this author at the Department of Chemistry, University of Bucharest, Faculty for Biology, Splaiul Independentei 95, Bucharest-5, R-76201, Romania; Tel: +4021.252 .2171 or +40726778426 ; Fax: +4021.318.1573; E-mail: pdiga49@yahoo.com
(TLC), silica gel for column chromatography, were from Merck. Bovine brain was purchased from a slaughter house and processed immediately. Galactocerebroside and sulfatide have been purified as described by [11].

\section{Methodology}

\section{NMR Spectra Registration}

${ }^{1} \mathrm{H}$ and ${ }^{13} \mathrm{C}$ NMR spectra of all intermediates, including galactofuranosylated glycosphingolipids, were registered in peracylated form in $\mathrm{CDCl}_{3}$ containing TMS. Constantly, the spectra of peracylated galactofuranoside have been referred to the spectra of peracetylated aglycone.

\section{A.One-Dimensional NMR Studies}

NMR experiments were performed on a Bruker Avance DRX 400 spectrometer using 400 and $100 \mathrm{MHz}$ for ${ }^{1} \mathrm{H}$ and ${ }^{13} \mathrm{C}$ frequencies, respectively.

\section{B.Two-Dimensional NMR Experiments}

The $1 \mathrm{H}-1 \mathrm{H}$ correlation spectroscopy $(\mathrm{COSY})$ and ${ }^{1} \mathrm{H}-{ }^{13} \mathrm{C}$ heteronuclear multiple quantum coherence (HMQC) experiments were carried out with an inverse probe.

IR spectra were recorded as $\mathrm{KBr}$ pellets on a Bruker Equinox 55 FT-IR spectrometer.

\section{Thin-Layer and Column Chromatography}

The following solvent systems (SS) were used for TLC: chloroform-methanol-water, 50:10:1 (v/v, SS I) and toluenemethanol, 7:1 (v/v, SS II). Visualization was made by dipping the plates in a solution of amonium molybdate, sulfuric acid and cerium(IV) sulfate, or in a $0.1 \%$ solution of ninhydrin in water saturated n-butanol for amino group containing compounds, followed by heating in both cases.

Column chromatography was made on Florisil or silica gel in a gradient of methanol in chloroform (0-40\%).

\section{Acidic Hydrolysis}

Total acidic hydrolysis was accomplished in a mixture of chloroform-ethanol-conc. $\mathrm{HCl}$ as indicated [11] while partial acidic hydrolysis was made in a $0.3 \mathrm{~N} \mathrm{HCl}$ solution in a 1:1 
mixture of ethanol-water [12]. In both cases, hydrolysis was monitored by TLC in SS I. Solvents were evaporated to dryness and the residue partitioned between chloroform and water. The two phases were separated, in water phase $D$ galactose was determined by anthrone reaction [11], while in chloroformic phase sphingosine (ninhydrin reaction) or galactocerebroside were determined [13].

\section{Periodic Acid Oxidation}

Synthetic glycoside (10-15 mg) was solved in a solution of methanol-water 1:1 containing $0.05 \mathrm{M}$ periodic acid and kept in the dark for $30 \mathrm{~min}$ [14]. Then formaldehyde was determined by reaction with chromotropic acid [15]. Oxidation of methyl $B$ - $D$-galactofuranoside (synthesized as indicated by [16]) as a control was also accomplished.

\section{Preparation of Acceptor Molecules}

Galactocerebroside was submitted to alkaline $\mathrm{N}$ deacylation and reacylation with stearoyl chloride [17, 18] and the main products purifed again. Tritylation was made according to [19], the tritylated product was acetylated and detritylated [20].

Sulfatide was N-deacylated and reacylated with stearoyl chloride $[17,18]$ and the main products purifed again. The acetylated product was desulfated with $p$-toluenesulfonic acid [20].

\section{Koenigs-Knorr Synthesis of Galactofuranosylated Galacto- cerebrosides}

The two isomeric partially acetylated galactocerebrosides were galactofuranosylated with 2,3,5,6-tetra-O-benzoyl- $\alpha-D$ galactofuranosyl bromide by using cadmium carbonate as promotor [21]. Penta-O-benzoyl- $\alpha \beta-D$-galactofuranose was obtained by benzoylation of dry $D$-galactose in hot pyridine $[21,22]$. Tetra-O-benzoyl- $\alpha-D$-galactofuranosyl bromide was prepared according to $[23,24]$.

\section{RESULTS}

Although half of the native glycosphingolipids, i. e., galactocerebroside and sulfatide were lost by alkaline $\mathrm{N}$ deacylation and reacylation with stearoyl chloride, homogenous glycosphingolipids, comparable with those produced by total synthesis, were obtained.

\section{B-D-Galactofuranosyl-6-B-D-galactopyranosyl- 1 'ceramide}

The sequence of reactions, for preparation of partially acetylated galactocerebroside, by tritylation-acetylationdetritylation of galactocerebroside, as well as its galactofuranosylation is described in Fig. (1).

\section{Galactocerebroside ( $\beta$-D-galactopyranosyl-1'ceramide)}

The galactocerebroside, obtained by chemical stearoylation of psychosine gave $D$-galactose, sphingosine and fatty acid in the molar ratio $1: 1: 1$, after total acidic hydrolysis. Anal. Calcd for $\mathrm{C}_{42} \mathrm{H}_{81} \mathrm{NO}_{8}$ : C, 69.28; H, 11.21. Found: C, 69.32; H, 11.28. NMR spectra of peracetylated galactocerebroside:

${ }^{1} \mathrm{H}-\mathrm{NMR}\left(\mathrm{CDCl}_{3} ; \delta, \mathrm{ppm} ; J, \mathrm{~Hz}\right): 4.46$ (d, 7.6, H-1), 5.38 (H-4), 5.31 (H-2), 5.02 (H-3), 4.14 (d, 6.8, H-6a and H-6b), 3.92 (dt, 6.4, H-5), 0.88 (methyl groups of ceramide), 1.25 (methylene groups of ceramide), 1.97, 2.03, 2.04, 2.15, 2.18 (methyl groups of acetate esters), 5.29 (H-4'), 5.83 (H-5'), 6.34 (NH of sphingosine).

${ }^{13} \mathrm{C}-\mathrm{NMR}\left(\mathrm{CDCl}_{3}\right): 100.90(\mathrm{C}-1), 68.68(\mathrm{C}-2), 70.82(\mathrm{C}-$ 3), 66.96 (C-4), 70.79 (C-5), 61.19 (C-6), 14.12 (methyl groups of ceramide), 20.95 (methylene groups of ceramide), 28.95-29.72 (methylene groups of ceramide), 129.91 (C-4'), 137.35 (C-5'), 169.44, 169.74, 170.73, 170.38 (C=O group of acetate ester).

\section{B-D-Galactopyranosyl(6-O-trityl)-1'ceramide and $\beta-D$ - Galactopyranosyl(2,3,4-tri-O-acetyl-6-O-trityl)-1'(3'-O- acetyl)ceramide}

Galactocerebroside ( $380 \mathrm{mg}, 0.52$ mmole) was dissolved in $10 \mathrm{~mL}$ of pyridine and $184 \mathrm{mg}(0.66 \mathrm{mmole})$ of trityl chloride was added [19]. The mixture was stirred for about $48 \mathrm{~h}$ at room temperature, the evolution of the reaction being followed by TLC in the SS I. When the reaction reached completion, the solvent was removed by rotavapor and the tritylated compound was separated from unreacted galactocerebroside by column chromatography on silica gel; oily product, yield $278 \mathrm{mg}(0.286 \mathrm{mmole}, 55 \%)$. Anal. Calcd for $\mathrm{C}_{61} \mathrm{H}_{95} \mathrm{NO}_{8}$ : C, 75.50; H, 9.87. Found: $\mathrm{C}, 75.54 ; \mathrm{H}, 9.96$. The product was peracetylated, reaction being quantitative. NMR spectra of peracetylated trityl derivative:

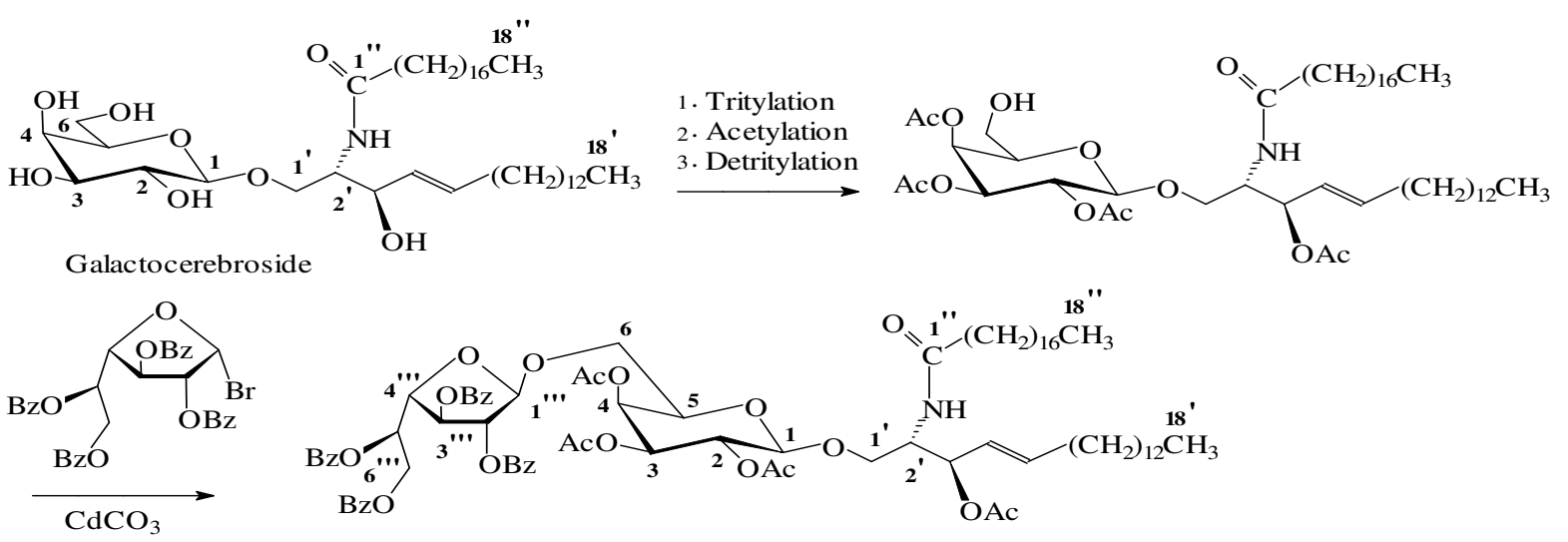

Fig. (1). Synthesis of B-D-galactofuranosyl (2', ,3', ,', ,6',-tetra-O-benzoyl)-6- $3-D$-galactopyranosyl (2,3,4-tri-O-acetyl)-1'(3'-Oacetyl)ceramide by using galactocerebroside as precursor. 
${ }^{1} \mathrm{H}-\mathrm{NMR}\left(\mathrm{CDCl}_{3} ; \delta, \mathrm{ppm} ; J, \mathrm{~Hz}\right): 4.40(\mathrm{~d}, 7.6, \mathrm{H}-1), 5.38$ (H-4), 5.31 (H-2), 5.02 (H-3), 3.91 (d, 6.8, H-6a and H-6b), 3.82 (dt, 6.4, H-5), 0.88 (methyl groups of ceramide), 1.25 (methylene groups of ceramide), 1.91, 1.94, 2.02, 2.10 (methyl groups of acetate esters), 5.80 (H-5'), 7.23, 7.25, 7.35, 7.37 (phenyl groups of trityl).

${ }^{13} \mathrm{C}-\mathrm{NMR}\left(\mathrm{CDCl}_{3}\right)$ : $100.76(\mathrm{C}-1), 68.86(\mathrm{C}-2), 72.07$ (C3), 67.10 (C-4), 70.97 (C-5), 58.27 (C-6), 14.05 (methyl groups of ceramide), 20.46 (methylene groups of ceramide), 28.84-29.65 (methylene groups of ceramide), 129.83 (C-4'), 137.22 (C-5'), 169.39, 169.62, 170.10 ( $\mathrm{C}=\mathrm{O}$ groups of acetate esters).

\section{B-D-Galactopyranosyl(2,3,4-tri-O-acetyl)-1'(3'-O- acetyl)ceramide}

Trityl-tetraacetyl-galactocerebroside $(320 \mathrm{mg}, \quad 0.281$ mmole) was stirred in a $20 \mathrm{~mL}$ mixture of dichlormethanemethanol, $1 / 1(\mathrm{v} / \mathrm{v})$ containing $p$-toluenesulfonic acid monohydrate [20] (350 mg, 1.84 mmole). The reaction was monitored carefully by TLC and when detritylation reached its optimum value, $p$-toluenesulfonic acid was immediately neutralized with an equivalent amount of sodium hydroxide. The solvent was removed and the detritylated product was separated by column chromatography of silica gel; yield 152.5 mg, 0.170 mmole, $60.5 \%$. Anal. Calcd for $\mathrm{C}_{50} \mathrm{H}_{89} \mathrm{NO}_{12}: \mathrm{C}$, 67.01; H, 10.01. Found: C, 67.05; H, 10.07. NMR spectra of partially acetylated galactocerebroside:

${ }^{1} \mathrm{H}-\mathrm{NMR}\left(\mathrm{CDCl}_{3} ; \delta, \mathrm{ppm} ; J, \mathrm{~Hz}\right): 4.46$ (d, 7.6, H-1), 5.38 (H-4), 5.31 (H-2), 5.02 (H-3), 4.14 (d, 6.8, H-6a and H-6b), 3.92 (dt, 6.4, H-5), 0.88 (methyl groups of ceramide), 1.25 (methylene groups of ceramide), 1.99, 2.03, 2.05, 2.12, 2.18 (methyl groups of acetate esters), 5.81 (m, 15.2, H-5').

${ }^{13} \mathrm{C}-\mathrm{NMR}\left(\mathrm{CDCl}_{3}\right): 101.32(\mathrm{C}-1), 69.20(\mathrm{C}-2), 71.11(\mathrm{C}-$ 3), 67.13 (C-4), 70.79 (C-5), 61.81 (C-6), 14.09 (methyl groups of ceramide), 20.96 (methylene groups of ceramide), 28.96-29.75 (methylene groups of ceramide), 129.87 (C-4'), 137.42 (C-5'), 169.64, 169.99, 170.37, $170.90(\mathrm{C}=\mathrm{O}$ groups of acetate esters).

IR Spectra of partially acetylated galactocerebroside, in comparison with partially acetylated tritylated galactocerebroside, indicated a significant absorption at $3250-3500 \mathrm{~cm}^{-1}$ due to hydroxy group on C-6 of sugar galactocerebroside. On the other hand, partially acetylated galactocerebroside migrated slower than peracetylated galactocerebroside.

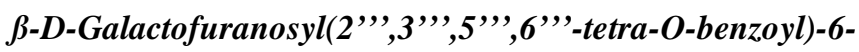 $\beta$-D-galactopyranosyl(2,3,4-tri-O-acetyl)-1'(3'-O- acetyl)ceramide}

In a flask protected against moisture, the following were added: $12-15 \mathrm{~mL}$ of dry toluene $(\mathrm{Na}), \beta-D$-galactopyranosyl (2,3,4-tri-O-acetyl)-1'(3'-O-acetyl)ceramide (140 mg, 0.156 mmole) $3 \mathrm{~g}$ of dry calcium sulfate and $3 \mathrm{~g}$ of cadmium carbonate $[21,25,26]$. The suspension was stirred for one hr at room temperature and then a solution of tetra-O-benzoyl- $\alpha$ $D$-galactofuranosyl bromide (133.2 $\mathrm{mg}, 0.202 \mathrm{mmole}$ ) in dry toluene $(10 \mathrm{~mL})$ was added and the suspension was heated to boiling point under stirring for 7-8 hr. Boiling was interrupted and 2 vols of chloroform were added to the reaction mixture while still warm. Suspension was filtered on Celite and the filtrate concentrated to dryness by rotavapor. Residue was resumed in a small volume of ethyl acetate and frac- tionated on a column of silica gel eluted with a gradient of ethyl acetate in hexane (0-50\%). A homogenous compound was separated from glycosylation mixture (Fig. 2); yield 105 $\mathrm{mg},(0.071 \mathrm{mmole}, 45.5 \%)$ white waxy solid. Anal. Calcd for $\mathrm{C}_{84} \mathrm{H}_{115} \mathrm{NO}_{21}$ :

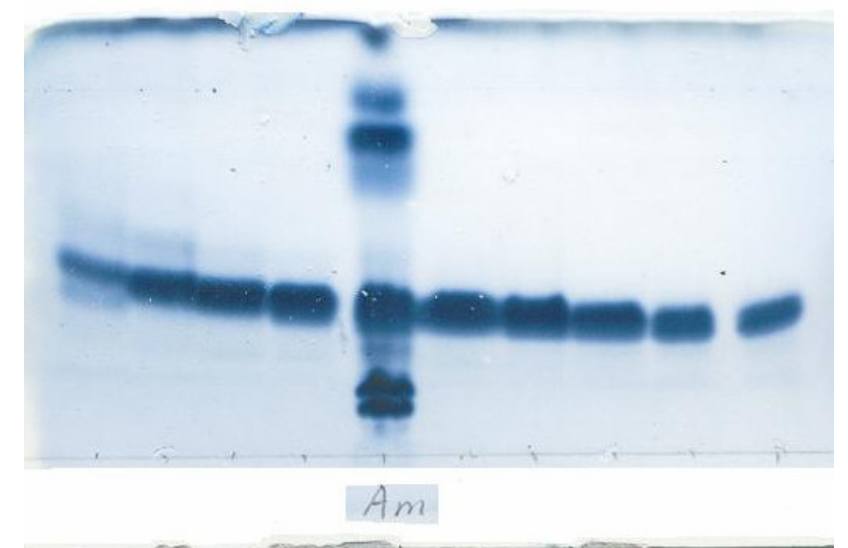

Fig. (2). Separation of $\beta$-D-galactofuranosyl $(2, ",, 3, ", 5, ",, 6,$, tetra-O-benzoyl)-6- $\beta$ - $D$-galactopyranosyl (2,3,4-tri-O-acetyl)-1'(3'$\mathrm{O}$-acetyl)ceramide from reaction mixture by column chromatography (in the middle, indicated by Am, initial crude product of glycosylation mixture). Migration with toluene-methanol, 7/1; visualization by mostain.

C, 68.41; H, 7.86. Found: C, 68.35; H, 7.92. NMR spectra of partially acetylated partially benzoylated glycoside:

${ }^{1} \mathrm{H}-\mathrm{NMR}\left(\mathrm{CDCl}_{3} ; \delta, \mathrm{ppm} ; J, \mathrm{~Hz}\right): 5.28$ (s, H-1','), 5.391 (H-2,', $), 5.71$ (H-3,', ), 5.51 (H-4,', ), 5.65 (H-5',' ), 4.79 (H6','a), 4.77 (H-6','b), 4.38 (d, 6.8, H-1), 5.16 (H-2), 4.97 (H-3), 5.35 (H-4), 3.94 (H-5), 4.72 (H-6a), 4.48 (d, 6.0, H6b), 0.86 (methyl groups of ceramide), 1.25 (methylene groups of ceramide), 1.96, 2.04, 2.07, 2.14 (methyl groups of acetate esters), 5.84 (H-5').

${ }^{13} \mathrm{C}-\mathrm{NMR}\left(\mathrm{CDCl}_{3}\right): 106.02$ (C-1',', $), 81.68$ (C-2,', $), 77.33$ (C-3','), 82.00 (C-4,',), 70.69 (C-5,',') 63.00 (C-6','), 101.02 (C-1), 69.56 (C-2), 71.48 (C-3), 68.00 (C-4), 71.33 (C-5), 62.35 (C-6), 14.09 (methyl groups of ceramide), 20.94 (methylene groups of ceramide), 27.19-31.90 (methylene groups of ceramide), 129.95 (C-4'), 133.60 (C-5'), 165.06, $165.48,165.70,166.01,169.58,169.87(\mathrm{C}=\mathrm{O}$ groups of acetate and benzoate esters).

After Zemplen saponification, the product migrated slower than native galactocerebroside, this feature disclosing its dihexosyl-ceramide structure. It contained $D$-galactose, sphingosine and fatty acid in the ratio $2: 1: 1$, as revealed by total acidic hydrolysis. Mild acidic hydrolysis gave galactocerebroside and $D$-galactose. All these chemical features indicated that the product of glycosylation has been $B-D$ Galactofuranosyl-6- $\beta-D$-galactopyranosyl-1'ceramide.

\section{B-D-Galactofuranosyl-3-B-D-galactopyranosyl- 1'ceramide}

The sequence of reactions, for preparation of partially acetylated galactocerebroside, by acetylation-desulfation of sulfatide, as well as its galactofuranosylation is described in Fig. (3). Sulfatide, produced by chemical stearoylation of psychosine sulfate, gave $D$-galactose, sphingosine, fatty acid and inorganic sulfate in the molar ratio $1: 1: 1: 1$. Contrary to 


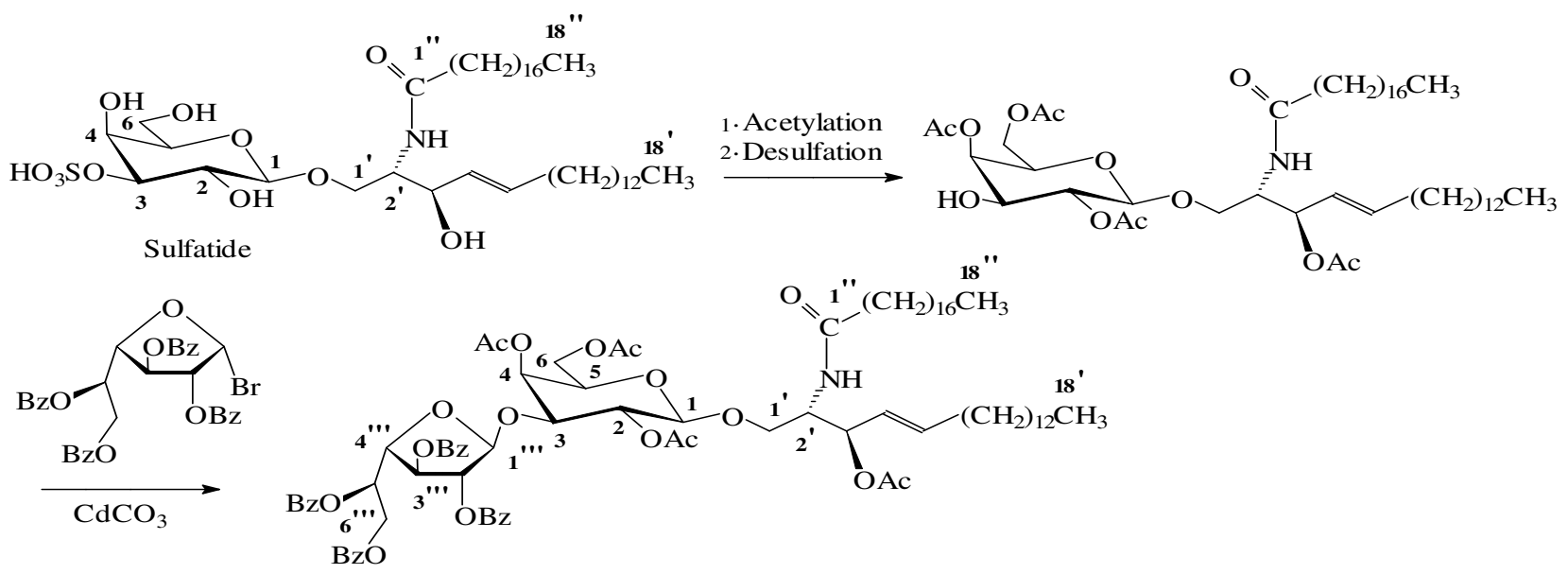

Fig. (3). Synthesis of $\beta$-D-galactofuranosyl (2,", ,3,", ,',',6','-tetra-O-benzoyl)-3-B-D-galactopyranosyl (2,4,6-tri-O-acetyl)-1'(3'-Oacetyl)ceramide from sulfatide.

galactocerebroside, sulfatide was retained by DEAESephadex A-25, being eluted with $0.25 \mathrm{M}$ sodium acetate methanolic solution [11]. IR Spectra indicated the presence of sulfate ester $\left(1240 \mathrm{~cm}^{-1}\right)$.

\section{Sulfatide (Cerebroside 3-sulfate)}

Sulfatide, produced by chemical stearoylation of psychosine sulfate, was peracetylated, the reaction being quantitative. Anal. Calcd for $\mathrm{C}_{42} \mathrm{H}_{80} \mathrm{NO}_{11} \mathrm{SNa}$ : C, 60.77; H, 9.71. Found: C, 60.80; H, 9.78. NMR spectra of peracetylated sulfatide:

${ }^{1} \mathrm{H}-\mathrm{NMR}\left(\mathrm{CDCl}_{3} ; \delta, \mathrm{ppm} ; J, \mathrm{~Hz}\right): 4.57$ (H-1), 5.38 (H-4), 5.00 (H-2), 5.29 (H-3), 4.07 (H-6a), 4.21 (H-6b), 3.85 (H-5), 0.88 (methyl groups of ceramide), 1.25 (methylene groups of ceramide), 1.99, 2.03, 2.06, 2.09 (methyl groups of acetate esters), 5.29 (H-4'), 5.83 (H-5'), 6.33 (NH of sphingosine).

${ }^{13} \mathrm{C}-\mathrm{NMR}\left(\mathrm{CDCl}_{3}\right)$ : $100.01(\mathrm{C}-1), 69.74(\mathrm{C}-2), 74.06(\mathrm{C}-$ 3), 73.42 (C-4), 67.03 (C-5), 62.32 (C-6), 14.09 (methyl groups of ceramide), 20.94 (methylene groups of ceramide), 28.98-29.72 (methylene groups of ceramide), 129.88 (C-4'), 137.14 (C-5'), 169.83, 171.02, $172.06(\mathrm{C}=\mathrm{O}$ groups of acetate esters).

\section{B-D-galactopyranosyl(2,4,6-tri-O-acetyl)-1'(3'-O- acetyl)ceramide}

Peracetylated sulfatide $(280 \mathrm{mg}, 0.280 \mathrm{mmole})$ was stirred in a $20 \mathrm{~mL}$ mixture of dichlormethane-methanol, 1/1 $(\mathrm{v} / \mathrm{v})$ containing $p$-toluenesulfonic acid monohydrate (365 $\mathrm{mg}, 1.91 \mathrm{mmole})$. Reaction was followed carefully by TLC and when desulfation reached its optimum value, $p$ toluenesulfonic acid was immediately neutralized with an equivalent amount of sodium hydroxide. Solvent was removed and desulfated product was separated by column chromatography of silica gel; yield $157.8 \mathrm{mg}, 0.176$ mmole, $62.8 \%$. Anal. Calcd for $\mathrm{C}_{50} \mathrm{H}_{89} \mathrm{NO}_{12}$ : C, 67.01; $\mathrm{H}, 10.01$. Found: $\mathrm{C}, 67.05 ; \mathrm{H}, 10.06$. NMR spectra of partially acetylated galactocerebroside:

${ }^{1} \mathrm{H}-\mathrm{NMR}\left(\mathrm{CDCl}_{3} ; \delta, \mathrm{ppm} ; J, \mathrm{~Hz}\right): 4.39$ (d, 7.2, H-1), 5.27 (H-4), 4.93 (H-2), 3.58 (H-3), 3.90 (H-6a), 4.10 (H-6b), 3.83 (H-5), 0.88 (methyl groups of ceramide), 1.25 (methylene groups of ceramide), 2.03, 2.06, 2.11, 2.18 (methyl groups of acetate esters), 5.76 (H-5').
${ }^{13} \mathrm{C}-\mathrm{NMR}\left(\mathrm{CDCl}_{3}\right): 100.66(\mathrm{C}-1), 69.60(\mathrm{C}-2), 71.15(\mathrm{C}-$ 3), 67.14 (C-4), 71.09 (C-5), 61.82 (C-6), 14.08 (methyl groups of ceramide), 20.67 (methylene groups of ceramide), 28.98-29.75 (methylene groups of ceramide), 129.88 (C-4'), 137.03 (C-5'), 169.64, 170.25, 170.91, 170.99 (C=O groups of acetate esters).

IR Spectra of partially acetylated galactocerebroside, in comparison with partially acetylated sulfated galactocerebroside, indicated a significant absorption at 3250-3500 $\mathrm{cm}^{-1}$ due to hydroxy group on C-3 of sugar galactocerebroside, as well as the dissapearance of absorption at $1250 \mathrm{~cm}^{-1}$ due to sulfate ester. At the same time, partially acetylated galactocerebroside migrated slower than peracetylated galactocerebroside.

\section{$\beta$-D-Galactofuranosyl(2,",,3,",,5,",6",'-tetra-O-acetyl)-3- $\beta$ - D-galactopyranosyl(2,4,6-tri-O-acetyl)-1'(3'-O- acetyl)ceramide}

A slightly different procedure was used in this case. $B-D$ Galactopyranosyl (2,4,6-Tri-O-acetyl)-1' (3'-O-acetyl)ceramide (142 mg, 0.158 mmole) was galactofuranosylated as indicated above with tetra-O-benzoyl- $\alpha$ - $D$-galactofuranosyl bromide (135.2 mg, $0.205 \mathrm{mmole}$ ). Reaction products were submitted to Zemplen hydrolysis and, after completion of the reaction, the mixture was neutralized and partitioned according to Folch. Glycolipids from chloroformic layer were chromatographed on a silica gel column. A compound migrating slower than galactocerebroside by TLC has been obtained with a yield of $59.8 \mathrm{mg}, 0.067$ mmole, $42.4 \%$, white waxy solid. Anal. Calcd for $\mathrm{C}_{48} \mathrm{H}_{91} \mathrm{NO}_{13}$ : C, 64.76; $\mathrm{H}$, 10.30. Found: $\mathrm{C}, 64.81 ; \mathrm{H}, 10.38$. The synthesis product gave galactocerebroside and $D$-galactose, by mild acidic hydrolysis. Total acidic hydrolysis produced $D$-galactose, sphingosine and fatty acid in the ratio $2: 1: 1$.

NMR spectra of peracetylated dihexosylceramide:

${ }^{1} \mathrm{H}-\mathrm{NMR}\left(\mathrm{CDCl}_{3} ; \delta, \mathrm{ppm} ; J, \mathrm{~Hz}\right): 5.44$ (s, H-1',') 4.87 (H-2', '), 5.05 (H-3','), 4.39 (H-4', '), 5.38 (H-5', '), 4.18 (H6",'a), 4.28 (H-6','b), 4.44 (d, 7.6, H-1), 5.01 (H-2), 4.05 (H-3), 5.35 (H-4), 4.03 (H-5), 3.94 (H-6a), 4.01 (H-6b), 0.86 (methyl groups of ceramide), 1.25 (methylene groups of ceramide), 1.95, 1.97, 2.05, 2.15, 2.18 (methyl groups of acetate esters), $5.80\left(\mathrm{H}^{-5}{ }^{\prime}\right)$. 
${ }^{13} \mathrm{C}-\mathrm{NMR}\left(\mathrm{CDCl}_{3}\right): 107.63$ (C-1','), 81 (C-2','), 76.69 (C-3','), 82 (C-4','), 68.67 (C-5','), 64.85 (C-6'”'), 101.20 (C-1), 69.55 (C-2), 73.18 (C-3), 70.82 (C-4), 67.22 (C-5), 61.35 (C-6), 14.09 (methyl groups of ceramide), 20.67 (methylene groups of ceramide), 27.21-31.91 (methylene groups of ceramide), 129.87 (C-4'), 137.17 (C-5'), 169.36, $170.15,170.34(\mathrm{C}=\mathrm{O}$ groups of acetate esters $)$.

It was inferred in this way that $\beta-D$-galactofuranosyl-3- $\beta$ $D$-galactopyranosyl-1'ceramide had been synthesized.

\section{DISCUSSION}

${ }^{1} \mathrm{H}$ And ${ }^{13} \mathrm{C}$ NMR characteristics given in this paper agreed well with similar values found in chemical literature for $\beta$ - $D$-galactofuranosic ring $[21,22,27-32]$ as well as of aglycone [33, 34].

In all cases production of formaldehyde by periodic acid oxidation constituted a supplimentary argument for furanosic ring of $D$-galactose.

Galactofuranosides, either natural [12, 35, 36], or synthetic, [21,37] are relatively vulnerable to acidic hydrolysis in comparison with galactopyranosides. Both galactofuranosylated glycosphingolipids synthesized in this paper, produced galactocerebroside and $D$-galactose by mild acidic hydrolysis, as could be evidenced by TLC in SS I.

$\beta$ - $D$-Galactofuranosyl-6- $\alpha \beta$ - $D$-galactopyranose, as a structural motif, was obtained by partial hydrolysis of immunologically specific polysaccharide of Mycoplasma mycoides [38] or of Mycobacterium tuberculosis [39]. Subsequently, this disaccharide was also synthesized [27] as well as two isomeric structural motifs, $B$ - $D$-galactofuranosyl-6and $B$ - $D$-galactofuranosyl-4-glucopyranose [28]

In this paper, by using galactocerebroside and sulfatide as precursors, $B-D$-galactofuranosyl-6- and $B$ - $D$-galactofuranosyl-3- $\beta-D$-galactopyranosyl-1'ceramide have been synthetized, respectively. An isomer of these compounds, longiside, $\quad \beta$ - $D$-galactofuranosyl-3- $\alpha-D$-galactopyranosyl1 'ceramide, was isolated from the Caribbean sponge Agelas longissima [29]. Ectyoceramide, $B$ - $D$-galactofuranosyl1 'ceramide, have been found in the marine sponge Ectyoplasia ferox [31]. It was proved unequivocally that agelagalastatin, $\alpha-D$-Galf-2- $\beta-D$-Galf-3- $\alpha-D$-Galp-1'Cer, isolated from a marine sponge, Agelas sp., presented significant in vitro inhibitory activity against human cancer cell lines including brain, kidney, colon, lung, ovary, melanoma [30]. On the other hand, it has been demostrated that dietary sphingolipids, due to their content in ceramides, play an active role in preventing cancer [40]. Moreover, they supress colon cancer induced by 1,2-dimethylhydrazine [10]. However, when orally administered, sphingolipids are digested and absorbed in the upper small intestine, which reduces the amount of bioactive molecules reaching the colon. A strategy to prevent this, consisted in synthesis of ceramide- $\beta$ - $D$-glucuronide [10]. Protection of glycosphingolipids or ceramides by galactofuranosylation could be a viable alternative to glucuronidation, a hypothesis supported by the fact that both enzymes, galactopyranosidase and galactofuranosidase, are produced by human colon flora [41, 42].

\section{ACKNOWLEDGEMENTS}

The authors are indebted to Prof. Richard R. Schmidt, Konstanz University, Germany, for expert advice and the helpful suggestions throughout this study as well as in the preparation of the manuscript. This work was supported in part by a CNCSIS research grant.

\section{CONCLUSIONS}

1. Galactocerebroside and sulfatide, two relatively accesible glycosphingolipids, disclosed a high chemical versatility both in their ceramide and sugar moiety. Two isomeric precursors, $B$ - $D$-galactopyranosyl (2,3,4-tri-O-acetyl)- and $B$ - $D$-galactopyranosyl $(2,4,6$ tri-O-acetyl)-1'(3'-O-acetyl)ceramide, were prepared from galactocerebroside and sulfatide, respectively.

2. Both precursors proved to be adequated glycosylation acceptors for $D$-galactofuranosyl group by KoenigsKnorr synthesis.

3. A good correlation was noticed between ${ }^{1} \mathrm{H}$ and ${ }^{13} \mathrm{C}$ NMR spectra and chemical means used used for characterization of both chemical intermediates and final products.

\section{REFERENCES}

[1] Van den Mooter, G. Expert. Opin. Drug Deliv., 2006, 3, 111-125.

[2] Yang, L.; Chu, J. S.; Fix, J. A. Internat. J. Pharmaceut., 2002, 235, 1-15.

[3] Jain, A.; Gupta, Y.; Jain, S. K. J. Pharm. Pharmaceut. Sci., 2007, 10, 86-128.

[4] Nakamura, J.; Kido, M.; Nishida, K.; Sasaki, H. Int. J. Pharm., 1992, 87, 59-66.

[5] Leopold, C. S.; Friend, D. R. J. Pharmacokinet. Biopharm., 1995 23, 397-406.

[6] Nakamura, J.; Asai, K.; Nishida, K.; Sasaki, H. Chem. Pharm. Bull., 1992, 40, 2164- 2168.

[7] Leopold, C. S.; Friend, D. R. Int. J. Pharm., 1995, 126, 139-145.

[8] Friend, D. R.; Chang, G. W. J. Med. Chem., 1985, 28, 51-57.

[9] Nolen, H. W.; Fedorak, R. N.; Friend, D. R. Biopharm. Drug Dispos., 1997, 18, 681- 695 .

[10] Schmelz, E. M.; Bushnev, A. S.; Dillehay, D. L.; Sullards, M. C.; Liotta, D. C.; Merrill, A. H.; Jr. Cancer Res., 1999, 59, 5768-5772.

[11] Iga, D. P.; Iga, S.; Larsson, T.; Angstrom, J.; Soussi, B.; Rakotonirainy, O.; Miller-Podraza, H. Glycoconjugate J., 1998, 15, 1111-1114.

[12] Clutterbuck, P. W.; Haworth, W. N.; Raistrick, H.; Smith, G.; Stacey, M. Biochem. J., 1934, 28, 94-110.

[13] Kates M. Techniques in lipidology. Isolation, analysis and identification of lipids. In: T. S. Work and E. Work (eds.), North-Holland Publishing Co. Amsterdam. 1972, Vol. 3: 269-610.

[14] Lederkremer, R. M.; Casal, O. L.; Alves, M. J. M.; Colli, W. FEBS Lett., 1980, 116, 25- 29.

[15] MacFadyen, D. A. J. Biol. Chem., 1945, 158, 107-133.

[16] Haworth, W. N.; Hirst, E. L.; Jones, D. I.; Woodward, H. J. Chem. Soc., 1938, 1575-1577.

[17] Erickson, J. S.; Radin, N. S. J. Lipid Res., 1973, 14, 133-137.

[18] Dubois, G.; Zalc, B.; Le Saux, F.; Baumann, N. Anal. Biochem., 1980, 102, 313-317.

[19] Bär, T.; Schmidt, R. R. Liebigs Ann. Chem., 1988, 669-674.

[20] Kodato, S.; Nakagawa, M.; Nakayama, K. Tetrahedron, 1989, 45, 7247-7262.

[21] Iga, D. P.; Iga, S.; Schmidt, R. R.; Buzas, M. C. Carbohydr. Res., 2005, 340, 2052-2054

[22] D'Accorso, N. B.; Thiel, I. M. E.; Schüller, M. Carbohydr. Res., 1983, 124, 177-184.

Barczai-Martos, M.; Koeroesi, F. Nature, 1950, 165, 369.

[24] Fletcher, H. G.; Jr. Methods Carbohydr. Chem., 1963, 2, 226-228.

[25] Conrow, R. B.; Bernstein, S. J. Org. Chem., 1971, 36, 863-879.

[26] Iida, T.; Nishida, S.; Yamaguchi, Y.; Kodake, M.; Chang, F. C.; Niwa, T.; Goto, J.; Nambara, T. J. Lipid Res., 1995, 36, 628-638.

[27] Marino, C. ; Varela, O.; de Lederkremer, R. M. Carbohydr. Res., 1989, 190, 65-76.

[28] Velty, R.; Benvegnu, T.; Gelin, M.; Privat, E.; Plusquellec, D. Carbohydr. Res., 1997, 299, 7-14. 
[29] Cafieri, F.; Fattorusso, E.; Mahajnah, Y.; Mangoni, A. Liebigs Ann. Chem., 1994, 1187-1189.

[30] Pettit, G. R.; Xu, J.-P. United States Patent 6,281,196, 2000.

[31] Costantino, V.; Fattorusso, E.; Imperatore, C.; Mangoni, A. Eur. J. Org. Chem., 2003, 1433-1437.

[32] Klotz, W.; Schmidt, R. R. Liebigs Ann. Chem., 1993, 683-690.

[33] Gasa, S.; Nakamura, M.; Makita, A.; Ikura, M.; Hikichi, K. Eur. J. Biochem., 1986, 155, 603-611.

[34] Li, L.; Tang, X.; Taylor, K. G.; DuPre, D. B.; Yappert, M. C. Biophys. J., 2002, 82, 2067-2080.

[35] Garcia Trejo, G. A.; Haddock, J. W.; Chittenden, G. J. F.; Baddiley, J. Biochem. J., 1971, 122, 49-57.

[36] Richards, J. C.; Perry, M. B. Can. J. Biochem. Cell. Biol., 1983, 61, $178-190$
[37]

[38]

[39] Vilkas, E.; Amar, C.; Markovits, J.; Vliegenthart, J. F.; Kamerling, J. P. Biochim. Biophys. Acta, 1973, 297, 423-435.

[40] Schmelz, E. M.; Dillehay, D. L.; Webb, S. K.; Reiter, A.; Adams, J.; Merrill, A. H.; Jr. Cancer Res., 1996, 56, 4936-4941.

[41] Englyst, H. N.; Hay, S.; MacFarlane, G. T. FEMS Microbiol. Lett., 1987, 45, 163-171.

[42] Friend, D. R. Glycosides in colonic drug delivery. in Oral ColonSpecific Drug Delivery. Friend DR. Ed. CRC Press, Boca Raton, 1992; pp. 153-187.

(C) Iga and Iga; Licensee Bentham Open .

This is an open access article distributed under the terms of the Creative Commons Attribution License (http://creativecommons.org/licenses/by/2.5/), which permits unrestrictive use, distribution, and reproduction in any medium, provided the original work is properly cited. 